\title{
New records and range extension of the recently reestablished Lamanonia ulei (Engl.) L.B. Sm. (Cunoniaceae): notes on taxonomy and conservation
}

\author{
Fernanda Santos-Silva ${ }^{1}$, Pedro Henrique Cardoso ${ }^{2}$, João Paulo Fernandes Zorzanelli ${ }^{3,4}$, \\ Andressa Cabral ${ }^{5}$
}

\begin{abstract}
1 Universidade Federal do Triângulo Mineiro, Campus Universitário de Iturama, Av. Rio Paranaíba, 1229, CEP 38280-000, Iturama, MG, Brazil. 2 Universidade Federal do Rio de Janeiro, Museu Nacional, Departamento de Botânica, Quinta da Boa Vista, CEP 20940-040, Rio de Janeiro, RJ, Brazil. 3 Instituto Nacional da Mata Atlântica, Av. José Ruschi 4, Centro, CEP 29650-000, Santa Teresa, ES, Brazil. 4 Universidade Federal do Espírito Santo, Núcleo de Pesquisa Científica e Tecnológica em Meio Ambiente, Silvicultura e Ecologia (NUPEMASE), Av. Governador Lindemberg 316, CEP 29550-000, Jerônimo Monteiro, ES, Brazil. 5 Universidade de São Paulo, Instituto de Biociências, Departamento de Botânica, R. do Matão 277, Cidade Universitária, CEP 05508-900, São Paulo, SP, Brazil.

Corresponding author: Fernanda Santos-Silva, fernanda.santos.silva@uftm.edu.br
\end{abstract}

\begin{abstract}
We report new records of the recently reestablished Lamanonia ulei (Engl.) L.B.Sm. (Cunoniaceae) from southeastern Brazil. This species is currently known by only eight specimens from Minas Gerais, Rio de Janeiro, and São Paulo states. We present seven new records that include Espírito Santo state in the species distribution, and expand its north and east limits of occurrence. We also present a taxonomic description, photos, occurrence map, conservation status assessment of L. ulei, and an identification key for all the species of Lamanonia Vell. from Brazil.
\end{abstract}

\section{Keywords}

Atlantic Forest, Geissoieae, Oxalidales, species distribution, Wallacean shortfall.

Academic editor: Ana Carolina Devides Castello | Received 8 May 2020 | Accepted 21 September 2020 | Published 15 October 2020

Citation: Santos-Silva F, Cardoso PH, Zorzanelli JPF, Cabral A (2020) New records and range extension of the recently reestablished Lamanonia ulei (Engl.) L.B. Sm. (Cunoniaceae): notes on taxonomy and conservation. Check List 16 (5): 1355-1360. https://doi.org/10.15560/16.5.1355

\section{Introduction}

Lamanonia Vell. (Cunoniaceae) currently comprises six species in southern Paraguay, northern Argentina, and central, eastern, and southern Brazil (Zickel and Leitão 1993; Hopkins 2018), where it is predominantly distributed in the Atlantic Forest domain (Santos-Silva et al. 2020), one of the global hotspots for biodiversity conservation (Myers et al. 2000). Together with Geissois Labill., Pseudoweinmannia Engl., and Karrabina Rozefelds \& H.C.Hopkins (genera from western side of the Pacific Ocean), Lamanonia is included in the tribe Geissoieae
(Bradford and Barnes 2001). It is distinguished from those genera for presenting free lateral stipules, simple axillary inflorescences, and stamens in more than one series (Hopkins 2018).

Since its description by Vellozo (1829), Lamanonia was subject to some important taxonomic treatments (e.g., Candolle 1830; Martius 1837; Bentham and Hooker 1862; Engler 1870, 1930; Kuntze 1891; Pampanini 1904; Glaziou 1906; Smith 1958; Biloni 1965; Cuatrecasas and Smith 1971). Subsequently, Zickel and Leitão (1993) 
presented a taxonomic revision of Lamanonia providing considerable information on its infrageneric taxonomy, which also included morphological descriptions, illustrations, identification key, and distribution maps. Since then, many information from biological collections has become available and, recently, Hopkins (2018) presented a nomenclatural update of this taxonomic treatment, providing details for all names and their synonyms, and designating lectotypes. One of the updates refers to the reestablishment of Lamanonia ulei (Engl.) L.B.Sm., after almost three decades as one of the synonyms of Lamanonia ternata Vell., a polymorphic species with wide distribution in South America (Zickel and Leitão 1993).

During the taxonomic review of Lamanonia for the "Flora do Brasil 2020" project, we analyzed material of L. ulei deposited in different collections of those studied by Hopkins (2018). Considering the importance of knowledge about the distribution of species for the systematics and conservation of biodiversity, we present an update on the distribution of $L$. ulei, including new records for the species, and also assessing its conservation status based on the new data. We present a description, photos, distribution map, and taxonomic, ecological, and geographic distribution comments. We also provide an identification key for all the species of Lamanonia from Brazil.

\section{Methods}

The studies were conducted based on the collections of the Botanischer Garten und Botanisches Museum Berlin-Dahlem Herbarium, Berlin, Germany (B), Leopoldo Krieger Herbarium, Federal University of Juiz de Fora, Minas Gerais, Brazil (CESJ), Herbarium Collection of the Museu de Biologia Mello Leitão, Espírito Santo, Brazil (MBML), P herbarium, Muséum National d'Histoire Naturelle, Paris, France (P), Rio de Janeiro Botanical Garden Herbarium Collection , Brazil (RB), and Herbarium Collection of the Espírito Santo Federal University, Espírito Santo, Brazil (VIES) (acronyms according to Thiers 2020). The material was examined in person, or through the Jabot (http://jabot.jbrj.gov.br) and RefloraHerbário Virtual (http://reflora.jbrj.gov.br/reflora/her barioVirtual) databases. Species identification was based on Zickel and Leitão (1993) and Hopkins (2018). Morphological terminology used in the species description is in accordance with Radford et al. (1974), Zickel and Leitão (1993), Font Quer (2001), and Hopkins (2018). Phenology and distribution data were gathered from specimen labels. Material examined is listed in alphabetical order by specific municipalities and localities. The distribution map was elaborated using QGIS v. 3.8 (QGIS Development Team 2018). Conservation status is in accordance with the IUCN Red List Categories and Criteria (2019). Area of Occupancy (AOO) and Extent of Occurrence (EOO) were inferred through Geospatial Conservation Assessment Tool (GeoCat; Bachman et al. 2011).

\section{Results}

Lamanonia ulei (Engl.) L.B.Sm., 1958; Journal of the Washington Academy of Sciences 48: 283.

Figure 1

Type. Brazil • E. Ule Herb. Brasil. 4551 [cited in protologue as 4581]. • Rio de Janeiro, Pedra do Cônico, Nova Friburgo; 17 Jan. 1898; 1300 m a.s.l.; lectotype, designated by Hopkins (2018), B109009682 (image); isolectotype HBG 506927 (image).

New records. BRAZIL • Espírito Santo, Afonso Cláudio, Serra Pelada, Pedra dos Três Pontões; 18 Jun. 2007; fl.; A.P. Fontana 3375 leg.; MBML 52534. • idem, except: Domingo Martins, Pedra do Colono e Pedra das Flores; 14 Aug. 1999; fr.; J.M.L Gomes 2571 leg.; VIES 35994. • idem, except: Iúna, Serra do Valentim; 01 Dec. 2013; fl.; J.P.F. Zorzanelli 893 leg.; VIES 33374. • Minas Gerais, Araponga, Serra da Araponga, Fazenda Neblina; Dec. 1994; fl.; L.S. Leoni 2729 leg.; RB 667503. • idem, except: Carangola, Morro da Torre; 23 Jun. 1990; fl.; L.S. Leoni 1137 \& C. Medeiros leg.; RB 667504 - idem, except: Durandé, Lemos, Comunidade rural Santa Maria, propriedade do Senhor João Carlos Neto; 08 Sept. 2013; fr.; A.C. Tuler 443 leg.; RB 607425. •idem, except: Lima Duarte, Serra Negra, Fazenda Serra Negra; 30 May 2009; fr.; F.S. Souza 682 \& J.H.C. Ribeiro leg.; CESJ 53527.

Previous known records. BRAZIL - Minas Gerais, Alto Caparaó, Parque Nacional do Caparaó, trilha Vale Verde; 02 Mar. 2010; fl.; G. Heringer et al. 210 leg.; RB 675999. - idem, except: Caratinga, Alto da Pedra Caratinga, Fazenda Silva; 17 Sept. 1929; fr.; I. Kuhlmann 7 leg.; RB 111079. • Rio de Janeiro: Nova Friburgo; no date; fl.; L.E. Paes 111 leg.; RB 56549. • idem, except: Petrópolis, Serra dos Órgãos; 23 Jul. 2017; fr.; J.M.A. Braga 17-025 leg.; RB 746516. • idem, except: Santa Maria Madalena, Pedra Dubois; 30 Aug. 2016; fl.; C. Baez et al. 985 leg.; RB 659921. • São Paulo, Serra da Bocaína; 18 May 1957; sterile; A.C. Brade leg.; RB 73894.

Identification. Trees 3-6.3 m height; branches cylindrical, glabrous, pubescent in the young region, trichomes ferruginous. Stipules 10-13 $\times 4-7 \mathrm{~mm}$, ovate, frequently deciduous. Leaves opposite, composite 3-foliolate; petiole 14-41 mm long, cylindrical, puberulous; lateral leaflets $47.5-100 \times 24.7-37 \mathrm{~mm}$, petiolule $2.6-3.4 \mathrm{~mm}$ long, median leaflets $65.2-155 \times 32.9-63 \mathrm{~mm}$, petiolule 4-11 mm long, strongly discolor, chartaceous, venation craspedodromous, elliptic to ovate, apex acuminate or acute, margin serrate, base cuneate to attenuate, adaxial surface lustrous, glabrous, midvein and secondary veins non prominent, midvein glabrous, rare glabrescent, abaxial surface opaque, densely tomentose, golden trichomes, midvein and secondary veins prominent, midvein tomentose, domatia present. Inflorescence axillary, racemose, axis $82.6-130 \mathrm{~mm}$ long, tomentose. Bisexual flowers, actinomorphic, monochlamydeous, white; pedicel 2-5 mm long, villous; sepals-6, united at the base, 

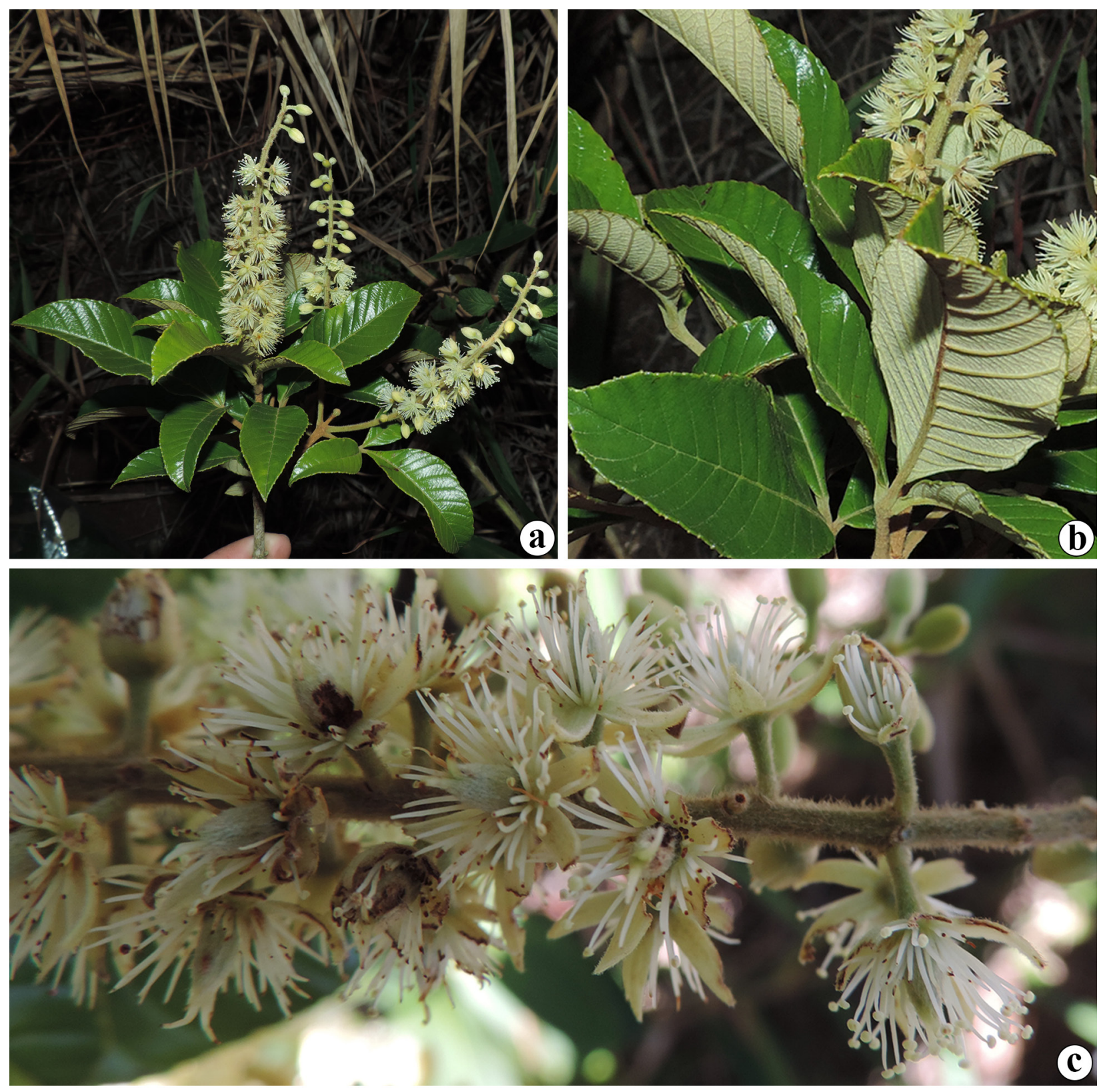

Figure 1. Habit of Lamanonia ulei (Engl.) L.B. Sm. (Cunoniaceae). A. Habit. B. Detail of strongly discolor leaves. C. Detail of inflorescence with golden indumentum visible in rachis. Photographs by Patricia da Rosa.

lanceolate, 4-6 mm long, apex acute, externally tomentose, margin ciliated; stamen numerous, 5.1-5.9 $\mathrm{mm}$ long, filament free, elongated, glabrous; anthers ovoid, 2-theca; superior-ovary, 2-carpelar, 2-locular, 2-5.5 mm long, densely villous, numerous ovules arranged in two longitudinal series; style 1-2 mm long, glabrous, capitate stigma. Septicidal capsule with partial loculicidal dehiscence, $11.2 \times 4.3-6 \mathrm{~mm}$, pubescent, brownish. Seeds numerous, winged, brownish, glabrous.

\section{Identification key to the species of Lamanonia in Brazil}

Based on Santos-Silva et al. (2020).

1. Inflorescence axis up to $6.5 \mathrm{~cm}$ long, ca 20 flowers, filaments hairy

L. chabertii

$1^{\prime}$. Inflorescence axis longer than $6.5 \mathrm{~cm}$ long, 30-40 flower, filaments frequently glabrous
2. Stipules semi-cordate, coriaceous, ca $1.5 \times 1.0 \mathrm{~cm}$.. L. speciosa

$2^{\prime}$. Stipules falcate, chartaceous, ca $0.4 \times 0.3 \mathrm{~cm} \ldots \ldots .3$

3. Fruit ovate to obovate, up to $1 \mathrm{~cm}$ long ... L. cuneata

3'. Fruit oblong or oblong-elliptic, longer than $1 \mathrm{~cm}$ long 4

4. Leaflets strongly discolor, abaxial surface densely tomentose, golden trichomes, veins prominent ....... L. ulei

4'. Leaflets concolor to slightly discolor, abaxial surface glabrous to pubescent, veins non-prominent .... 5

5. Leaflets coriaceous, usually glabrous, flowers with ca 40 stamens L. brasiliensis

5'. Leaflets chartaceous, usually hairy, flowers with 2530 stamens

L. ternata 
Ecological comments. Lamanonia ulei occurs in an elevation range of 1000-1800 $\mathrm{m}$ a.s.l. in open field areas, areas in transition to campos de altitude, cloud dwarf forests, riparian forests, and secondary forests. It was found with flowers during March, June, August, September, and December, and with fruits in July and August.

Conservation status. Lamanonia ulei presents an EOO of $42,997 \mathrm{~km}^{2}$ and an AOO of $52 \mathrm{~km}^{2}$. According to IUCN (2019), this species should be classified as Endangered, due the estimated AOO of less than $500 \mathrm{~km}^{2}$. However, considering that its populations occur in protected areas (Parque Nacional do Caparaó, Parque Estadual do Desengano, Parque Estadual da Pedra Azul, Parque Estadual da Serra Negra da Mantiqueira), L. ulei can be considered as Vulnerable, B2ab(ii, iii). It is noteworthy that some occurrences are on private property. Considering the recent changes in the Brazilian Forest Code (Brasil 2012), these populations might be at greater risk.

\section{Discussion}

Engler (1930) published the basionym of Lamanonia $u l e i$, distinguishing his new species by the dense, grey, felty indumentum on the lower surface of the leaflets.
Zickel and Leitão (1993) considered that the morphology of the only specimen examined of L. ulei (type specimen) was a local variation of $L$. ternata, with these characteristics related to xeric environments. These authors also supported this interpretation considering that Leite (1983) visited the type location of L. ulei (Pedra do Cônego, Nova Friburgo, Rio de Janeiro state), located one individual that was identified as L. ternata, and indicated that $L$. ulei should be considered synonym of $L$. ternata. Consequently, for almost 30 years, L. ulei was considered a synonym of the widespread L. ternata. In a generic synopsis, Hopkins et al. (2013) indicated the $L$. ulei should be recognized as a species and, later, Hopkins (2018) reestablished L. ulei, after examining the type specimens and additional specimens deposited in seven collections available at that moment. During our work on the "Flora do Brasil 2020" project, we analyzed seven additional specimens and were able to confirm the identity of $L$. ulei (i.e., the stability of its diagnostic characters as strongly discolored leaves with golden indumentum, and prominent veins on abaxial surface) along its geographical distribution (Fig. 2).

Lamanonia ulei is currently considered endemic in Southeastern Brazil, restricted to the Atlantic Forest

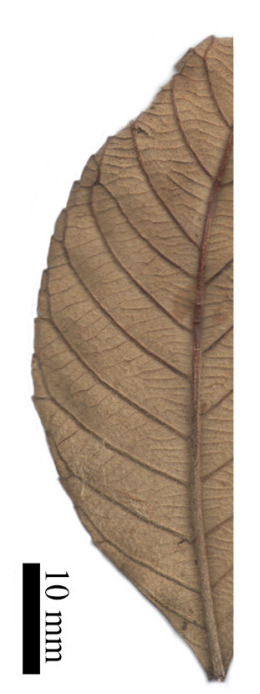

(a)

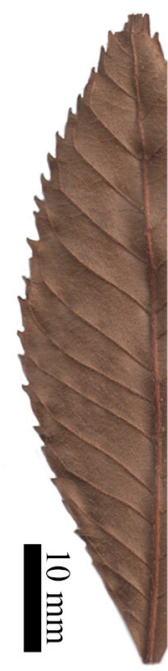

(b)
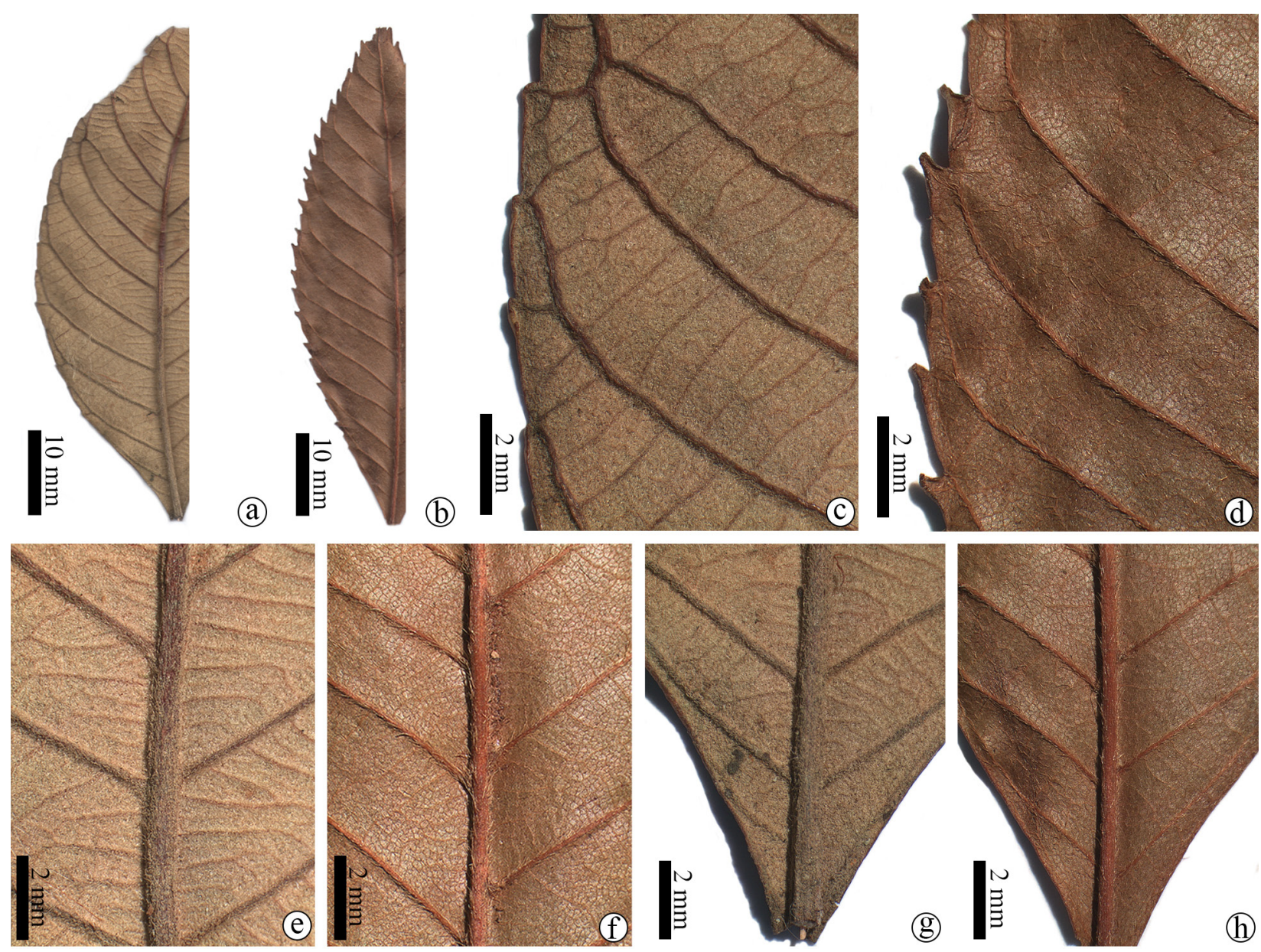

Figure 2. Comparison of Lamanonia ulei (Engl.) L.B. Sm. and L. ternata Vell. (Cunoniaceae) leaves. A. L. ulei, general abaxial view. B. L. ternata, general abaxial view. C. L. ulei, margin, tertiary veins are visible. D. L. ternata, margin, tertiary veins are not visible. E. L. ulei, middle portion. F. L. ternata, middle portion. G. L. ulei, base, primary and secondary veins tomentose. H. L. ternata, base, primary and secondary veins sparse pubescent. 
domain. It is distributed in Rio de Janeiro, São Paulo, and Minas Gerais states (Hopkins 2018). Based on three records deposited in Brazilian herbaria, we recorded for the first time its occurrence in Espírito Santo state. Recent studies (Luber et al. 2016; Zorzanelli et al. 2017; Araújo et al. 2018) have highlighted the existence of gaps in floristic knowledge in the state, especially in undersampled regions such as the south. Collection efforts in protected and unprotected areas in this region revealed new records of plant species in sites still poorly studied, as in vegetation located in almost inaccessible mountains (Araújo et al. 2018). Thus, the three new occurrences of L. ulei to Espírito Santo state, located in humid vegetation above $1000 \mathrm{~m}$ elevation, illustrate the lack knowledge of the richness of the flora in this state, a challenge faced by the "Flora do Estado do Espírito Santo" project, whose objective is to monograph all botanical families through a network of researchers (Dutra et al. 2015). The new records in Espírito Santo state increase range distribution of L. ulei to the north and east (Fig. 3).

Hopkins (2018) gave a provisional Red List status of Near Threatened for L. ulei and considered the EOO $\left(27,503 \mathrm{~km}^{2}\right)$, AOO $\left(24 \mathrm{~km}^{2}\right)$, and the assumed lack of more information about distribution and occurrence in protected areas. However, with the new records presented here, we are able to refine the status of this species as Vulnerable. Both EOO and AOO are increased $\left(42,997 \mathrm{~km}^{2}\right.$ and $52 \mathrm{~km}^{2}$, respectively) and the presence of L. ulei is confirmed in four distinct protected areas of Espírito Santo, Minas Gerais, and Rio de Janeiro states.

The first record of L. ulei in Espírito Santo and additional ones in Minas Gerais emphasize that the knowledge about the distribution of taxa in the Atlantic Forest, mainly regarding to the mountains of southeastern Brazil, is still underestimated. Due to the vulnerability of the montane vegetation to anthropogenic environmental changes, our study contributes to the management and conservation of L. ulei populations and its habitats. Our study also highlights the need to increase the collection effort and taxonomic studies dedicated to contribute to the discovery of a diversity still unknown in the Atlantic Forest.

\section{Acknowledgements}

We thank the herbarium CESJ for providing lab infrastructure, Patricia da Rosa (CNCFlora-JBRJ) for all pictures of Lamanonia ulei in the habitat, and Rafael Barbosa-Silva for the distribution map. PHC thanks the National Council for Scientific and Technological Development (CNPq) for the doctoral scholarship (process \#141837/2020-9). AC thanks the State of São Paulo Research Foundation (FAPESP) for the master's scholarship (process \#2017/09447-9). The authors also thank the subject editor and reviewers for their helpful insights on the manuscript.

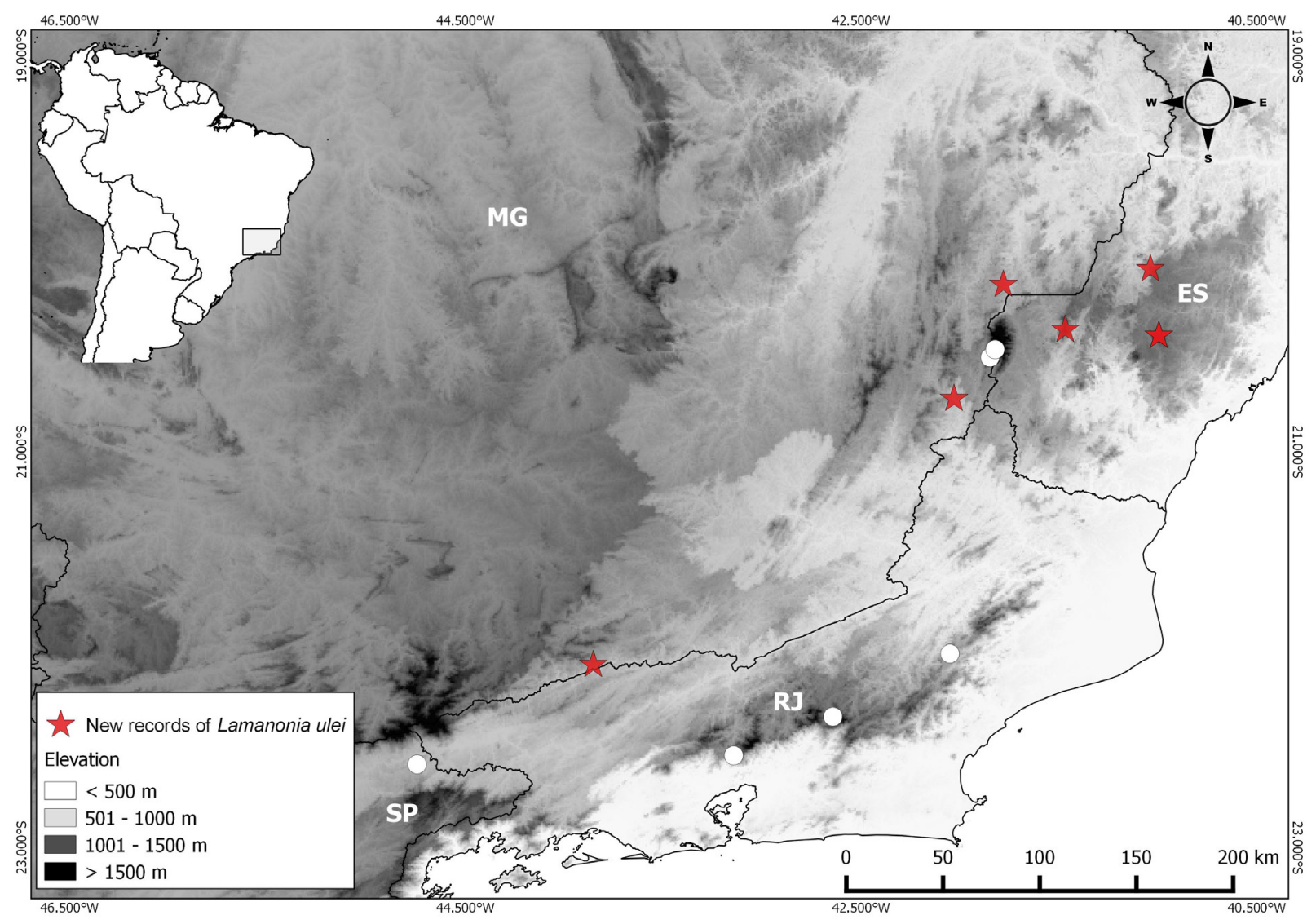

Figure 3. Distribution map of Lamanonia ulei (Engl.) L.B. Sm. (Cunoniaceae). Red stars: new records. White circles: previous known records. 


\section{Authors' Contributions}

FSS, PHC, and AC contributed to the study conception and design. Preparation of materials, data collection, and analysis were performed by FSS, PHC, JPFZ, and AC. The first draft of the manuscript was written by FSS and $\mathrm{AC}$, and all authors commented on subsequent versions of the manuscript. All authors read and approved the final manuscript version.

\section{References}

Araújo EA, Kunz SH, Dias HM, Carrijo TT, Zorzanelli JPF (2018) Inventários florísticos na região do Caparaó Capixaba revelam novos registros para a flora do Espírito Santo. Rodriguésia 69 (4): 1953-1963. https://doi.org/10.1590/2175-7860201869429

Bachman S, Moat J, Hill AW, de la Torre J, Scott B (2011) Supporting Red List threat assessments with GeoCAT: geospatial conservation assessment tool. ZooKeys 150: 117-126. https://doi.org/ 10.3897/zookeys.150.2109

Bentham G, Hooker JD (1862) Saxifragaceae. In: Bentham G, Hooker JD (Eds) Genera plantarum. A. Black, London, 629-655.

Biloni JS (1965) Notas preliminares a una revisión de las Cunoniáceas argentinas. Boletin de la Sociedad Argentina de Botanica 10: 292-301.

Bradford JC, Barnes RW (2001) Phylogenetics and classification of Cunoniaceae (Oxalidales) using chloroplast DNA sequences and morphology. Systematic Botany 26: 354-385. https://doi. org/10.1043/0363-6445-26.2.354

Brasil (2012) Novo Código Florestal. Lei n 12.651, de 25 de maio de 2012. Brasília, Diário Oficial da União. http://www.planalto.gov.br/ ccivil_03/_ato2011-2014/2012/lei/112651.htm. Accessed on: 20209-4.

Candolle AP de (1830) Saxifragaceae. In: Candolle AP de (Ed) Prodromus systematis naturalis regni vegetabilis, pars IV. Treuttel et Wurtz, Paris, 1-13.

Cuatrecasas J, Smith LB (1971) Cunoniáceas. In: Reitz R (Ed) Flora ilustrada catarinense, part I. Herbário Barbosa Rodrigues, Itajaí, $1-22$

Dutra VF, Alves-Araújo A, Carrijo TT (2015) Angiosperm checklist of Espírito Santo: using electronic tools to improve the knowledge of an Atlantic Forest biodiversity hotspot. Rodriguésia 66 (4): 1145-1152. https://doi.org/10.1590/2175-7860201566414

Engler A (1870) Monographische Uebersicht der Gattungen Escalonia Mutis, Belangera Camb. und Weinmannia L. nebst Beiträgen zur geographischen Verbreitung der Escallonieen und Cunoniaceen. Linnaea 36: 527-650.

Engler A (1930) Cunoniaceae. In: Engler A, Prantl K (Eds) Die natürlichen Pflanzenfamilien, 2nd ed. W. Engelmann, Leipzig, 229-262.

Font Quer P (2001) Diccionario de botánica, 2nd ed. Ediciones Península, Barcelona, $1244 \mathrm{pp}$

Glaziou AFM (1906) Plantae Brasiliae centralis a Glaziou lectae. Liste des plantes du Brésil central recuillies en 1861-1895. Mémoires publiés par la Société botanique de France 3: 1-661. https://doi. org $/ 10.5962 /$ bhl.title. 4336

Hopkins HCF (2018) Names and types relating to the South American genus Lamanonia (Cunoniaceae) and its synonyms, the identity of $L$. speciosa, and an account of the little-known L. ulei. Kew Bulletin 73: 10. https://doi.org/10.1007/s12225-017-9731-4

Hopkins HCF, Rozefelds AC, Pillon Y (2013) Karrabina gen. nov. (Cunoniaceae), for the Australian species previously placed in Geissois, and a synopsis of genera in the tribe Geissoieae. Australian Systematic Botany 26: 167-185. https://doi.org/10.1071/ SB12037

IUCN Standards and Petitions Committee (2019) Guidelines for using the IUCN Red List categories and criteria. Version 14. Prepared by the Standards and Petitions. http://www.iucnredlist.org/ documents/RedListGuidelines.pdf. Accessed on: 2020-9-4.

Kuntze CEO (1891) Revisio generum plantarum, vol. 1. Arthur Felix, Leipzig, 374 pp.

Leite NAS (1983) Estudos taxonômicas e morfológicos sobre $\mathrm{La}$ manonia ternata (Cunoniaceae). Arquivos da Universidade Federal Rural Rio de Janeiro 6: 49-64.

Luber J, Tuler AC, Leite FT, Christ JA, Guidoni-Martins KG, Zanetti M, Hollunder RK, Manhães VDC, Zorzanelli JPF, Mendonça EDS, Garbin ML, Carrijo TT (2016) List of angiosperm species in an Atlantic Forest fragment reveals collection gaps in Espírito Santo state, Brazil. Check List 12 (1): 1-10. https://doi. org $/ 10.15560 / 12.1 .1835$

Martius CFP von (1837) Herbarium florae brasiliensis. Flora 20 (2, Beibl.): 1-128.

Myers N, Mittermeier RA, Mittermeier CG, Fonseca GAB, Kent J (2000) Biodiversity hotspots for conservation priorities. Nature 403: 853-858. https://doi.org/10.1038/35002501

Pampanini R (1904) IX. Description d'une nouvelle Cunoniacée du Brésil. Annuaire du Conservatoire et du jardin botaniques de Genève 7-8: 328-329.

QGIS Development Team (2018) QGIS Geographic Information System. Version 3.8. Open Source Geospatial Foundation Project. https://www.qgis.org. Accessed on: 2019-10-14.

Radford AE, Dickinson WC, Massey JR \& Bell CR (1974) Vascular plant systematics. Harper Collins, New York, 891 pp.

Santos-Silva F, Cabral A, Cardoso PH (2020) Cunoniaceae in Flora do Brasil 2020 (em construção). http://floradobrasil.jbrj.gov.br/ reflora/floradobrasil/FB96. Accessed on: 2020-2-22.

Smith LB (1958) Notes on South American phanerogams - I. Journal of the Washington Academy of Sciences 48: 282-284

Thiers B (2020) Index herbariorum: a global directory of public herbaria and associated staff. [continuously updated]. http:// sweetgum.nybg.org/science/ih/. Accessed on: 2020-2-22

Vellozo JMC (1829) Florae fluminensis. Typographia nationali, Flumine Januario [= Rio de Janeiro], 228 pp. [dated 1825, published 1829].

Zickel CS, Leitão Filho HF (1993) Revisão taxonômica de Lamanonia Vell. (Cunoniaceae). Revista Brasileira Botânica 16: 73-91.

Zorzanelli JPF, Dias HM, Silva AG, Kunz SH (2017) Vascular plant diversity in a Brazilian hotspot: floristic knowledge gaps and tools for conservation. Brazilian Journal of Botany 40 (3): 819 827. https://doi.org/ 10.1007/s40415-017-0386-Z 